\title{
The Chinese new Civil Code and the law of contract
}

\author{
Jacques Henri Herbots ${ }^{1}$
}

Accepted: 8 September 2021 / Published online: 9 November 2021

(c) China-EU School of Law 2021

\begin{abstract}
The purpose of this contribution is to present to the readers the Chinese Civil Code which entered into force the first of January 2021, and to bring to their attention the changes brought about in the law of contract, now contained in Book III of the Civil Code. The importance of this major event of 2020 in the world of comparative law nearly went unnoticed due to the predominance in these days of the Corona virus coverage in the press. The Act which is the only one in the People's Republic bearing the name «code» (Civil Code=Min Fadian) was adopted by the National People's Congress on May 28, 2020.
\end{abstract}

Keywords Chinese $\cdot$ New $\cdot$ Civil $\cdot$ Code $\cdot$ China

\section{The code}

\subsection{The dream of a codification}

It has been the long-cherished wish of generations of civil law scholars in China to follow the continental European tradition of codification, and to create a codex which regulates exclusively and completely, in a systematic way, without contradictions, a comprehensive part of the law. In contrast with the historical resistance of the Common-Law tradition against the idea of codification of the private law, civil law jurisdictions indeed rely on codification. Mainland China is a civil law jurisdiction since the beginning of the Republic.

It must be said that the first permanent system of codified laws could be found in imperial China with the compilation of the Tang Code in 624 after Christ, later followed by those of the Song or Ming dynasties or in the last dynasty by the $D a$ Qing L Lï Li. The imperial Codes, however, were mainly concerned with criminal law and administration, and not at all with civil law. During the late Qing dynasty emperor Guang $X u$ mandated a special hand-picked committee to draft a Western

Jacques Henri Herbots

jherbots2012@yahoo.com

1 KU Leuven, Leuven, Belgium 
style Civil Code for China, but it would never be enacted. The republic was proclaimed in 1911. After the formation of a national government in 1928, a legislative committee was charged to draft a Civil Code following the model of Guang Xu. It was successful. The first Chinese Civil Code, following mainly the model of the German BGB, was enacted in 1930. It is still in force in Taiwan, but in the PRC it was, together with the whole legislation enacted under Chang Kai-shek repealed in 1949. Twice during the Mao period China attempted to draft a new Civil Code, in 1954 inspired by the Soviet law, and in 1962. The attempts failed. After the opening of the PRC in 1978 under the de facto leadership of Deng Xiaoping the legislative process which eventually would lead in 2020 to the enactment of the new Civil Code started with the promulgation in 1986 of the General Principles of Civil Law (156 articles in 9 chapters). The drafters had dreamed to create the new Civil Code, but realized that the time was not ripe yet for such an ambitious project. Unlike the Civil Codes of France and Germany, the Chinese Civil Code would not take shape all at once. Step by step the Civil law would be shaped in separate laws: for the law of contracts for instance the guarantee law (1995), contracts (1999), property and real rights (2007), torts (2009), private international law (2010). In 2010 a draft of a Civil Code would be presented to the 150 members of the Standing Committee of the National People's Congress. In 2014 the Chinese Communist Party put the codification of the civil law on the political agenda. Then the takeoff could take place. A team of approximately 20 members took over in 2015 as drafting commission. It was composed of professors of the Renmin and the Tsinghua University, members of the Supreme People's Court, the procuratorate of the People's Supreme Court, the ministry of Justice, and the Chinese association of lawyers (Prof. Wang Liming). What would become, according to the German model, the first Book of the Civil Code, namely the General Provisions of the Civil Law (in fact a remake of the Act of 1986, cited above) was enacted in 2017. After ten rounds of open consultation of the public (during which for instance the women's organizations expressed strong criticism against the proposed cooling off period before a divorce, and other participants proposed to introduce same-sex marriage in Book V on family law) the NPC passed the new Civil Code in May 2020. Finally all the Laws compiled in the Civil Code were repealed the day the new Code came to life.

\subsection{A compilation of existing laws}

The Chinese Civil Code aims to systematically integrate, in 1260 articles, all the existing legal norms in the field of civil matters. It is a further development of China's civil law tradition (German, Swiss and Japanese law), starting with the structure of the Code. It is divided in seven Books: General Provisions (the "Algemeiner Teil" of the BGB), Property, Contracts, Personality Rights, Family Law, Succession, and Torts.

The so-called codification of 2020 is rather a re-grouping of existing minicodes, a compilation without touching the essence of the existing articles. It was no remodeling of the private law, no rethinking of the existing texts, - - what implies 
innovation, endorsing a unifying idea. ${ }^{1}$ This has, however, been the case, for each separate law, for instance after a long legislative process for the Property Law of 2007. The political basement under the new Civil Code is implicitly the idea of the socialist market economy and the doctrine of Xi Jinping. It is remarkable that the case law of the Supreme People's Court is treated as a real source of law, on equal footing with the statutory law.

Let us take as example article 533 on the doctrine of hardship. Book III is mainly based on the previous Contract Law of 1999, as well as on the judicial interpretations of the Chinese Supreme People's Court. The general assembly of the NPC, before the vote of the Contract law, had rejected the doctrine of "hardship" (called the doctrine of the unforeseen change of the situation, "Qing shí bian geng"). However, ten years later, after the international bank crisis following the collapse of the Lehman Brothers Bank, in the Second Interpretation of the Contract Act of 13 May 2009 and in the guiding opinion of 7 July 2009 the doctrine of hardship was formally recognized by the Supreme People's Court. ${ }^{2}$ The new article 533 of the Civil Code incorporates this judicial interpretation. That is certainly an important improvement to the law of contract, but it was already adopted in the case law. However, article 533 does not require anymore that the change in circumstances shall not be caused by force majeure.

\subsection{The legitimation of the private law}

An important feature of the Code is its effort to legitimize private law. For the first time in the history of communist China State interests and private interests are treated equally. China never underwent a large scale privatization, unlike Russia where a massive privatization took place after 1989. The private sector has been growing in China at an exponential speed outside the State sector, despite the lack of legal and ideological certainty. This happened while the ideological and doctrinal debates about the recognition of private law in a socialist regime have been ongoing over the past 40 years. The recognition of private ownership has always been a major ideological hurdle in the law-making of the PRC since the 1950's. For decades after 1949, private law was abolished and private interests unprotected. The 1954 Constitution set the clear goal to transform private ownership into socialist public ownership. Starting in 1954, government regulations required that private enterprises be converted into public-private joint ventures with the State. In 1956, all private owned enterprises were transformed into public-private joint ventures, which soon became de facto State-owned enterprises. By the end of that year, only 0,5 per cent of private enterprises had not yet been transformed into public-private

\footnotetext{
1 See about the idea of codification: VANDERLINDEN, J., "Le concept de code en Europe occidentale du XIIIe au XIXe siècle. Essai de définition.”, Bruxelles, 1967; OPPETIT, B., Essai sur la codification, PUF, 1998.

${ }^{2}$ Herbots J.H., "Contracteren in China", Larcier, 2008; "Contracts in the People's Republic of China. An outline of the Chinese law from the perspective of Europe and Hong Kong", die Keure, 2018.
} 
joint ventures. In the 1975 Constitution, the protection of private ownership was finally discarded, and only public ownership was inviolable according to its article 8.

After the economic reform of 1978 under Deng Xiaoping and the establishment of a socialist market economy in 1993, the ideology has shifted towards protection of the private economy and a system of private law has been steadily and gradually developed. A Contract Law was enacted in 1999, as said above, a Property Law in 2007. This long awaited Act on ownership and rights in rem illustrates the difficulties encountered by the drafters of the Civil Code. Fourteen years passed since the said law was put on the parliamentary agenda in 1994. One may imagine the heated discussions in the commission with the fanatic defenders of the Marxist-Leninist doctrine, for which private ownership is anathema! In 1988 a Constitutional amendment permitted "the private sector of the economy to exist and develop within the limits prescribed by law". Later, the private sector of the economy was regarded as "a complement to the socialist public economy". Article 16 of a Constitutional amendment of 1999 elevated the status of the private economy to "a major component" of the economy. In 2004, a Constitutional amendment provided that private ownership is inviolable (article 22). Today, private economy makes up for more than half of the Chinese economy, and the commitment to protect private interests is absolutely critical to the growth of China. This commitment to equal protection of State and private interests is duly recognized by article 207 of the Civil Code: "Property rights of the State, of collectives and private individuals along with property rights of others receive equal protection under the law; no organization or individual shall infringe these rights." 3

\subsection{Pedagogical (rather than scientific) purpose of the code}

The new Civil Code includes some new provisions. A new provision for instance concerns the "seat thieves", introduced after a hype in the media. Several videos about people in China rudely refusing to move despite being seated somewhere they shouldn't be-in a seat for handicapped people in the subway or in a seat in a long distance train assigned to someone else for instance- have gone viral on the Chinese internet. Article 815 of the Civil Code addresses this issue, stating that passengers must adhere to what is mentioned on their transport ticket: seat number, time, as well as train number. If they take a train for which they don't have a ticket, they must pay the difference in price between the two fares, and may be refused service by railway personnel. This simple example illustrates the pedagogical ambition of the Civil Code, instead of a juridical-science ambition, like the one the German drafters had in 1900. The drafters of the Chinese Civil Code were not concerned with shrill legal science.

\footnotetext{
${ }^{3}$ Hao Jiang (now professor at the Bocconi university in Milano), James Gordley and Arthur von Mehren, "An introduction to the comparative study of private law. Readings, cases, materials", Cambridge University Press, 2020.
} 


\subsection{The trust is left out of the Civil Code}

The Chinese Civil Code continues the civil law tradition followed in China since the very beginning of the reception of the Western law in China. A characteristic indication of this is that the institution of the trust-par excellence an institution which is peculiar to the Common-Law-is left out of the Civil Code. One remembers the origin of the trust in the English middle-ages: a knight crusader would before his departure on the dangerous journey to Jerusalem transfer his assets for the later benefit of his young heir to a trusted person. He did so for fiscal reasons, while the transfer to the heir, if the knight did not return from the crusade, would escape the royal succession rights. For the Common Law courts the trustee was the legal owner. The "equitable" rights of the beneficiary were, however, protected by the Chancery court. This legal device (called "use" in the beginning) was abolished at a certain moment, but preserved under the name "trust" in the case law in equity of the Chancery court. Continental lawyers did not understand the trust institution. The separation of the legal ownership of the trustee from the equitable ownership of the beneficiary is incompatible with the "numerus clausus" rule of the civil law, and its rule that a person has only one "patrimony". Anyhow, while trusts are useful in the world of banks and financial institutions, they were introduced in the PRC by the Trust Law of 2001. Trust ("xin tuo") was, however, not conceptualized in the law. ${ }^{4}$ One could speculate whether the Chinese legislator would incorporate the trust in the new Civil Code. This did not happen. The trust Law is retained as a separate law for financial institutions. Trust is mentioned only once in the final version of the Civil Code. Article 1133, $\S 4$ provides that "a natural person may establish a testamentary trust according to the law". This absence could be interpreted as an opening left to the "contractualisation" of the trust. Nothing indeed prohibits the drafting of an innominate (trustlike) fiduciary contract. This absence indicates at the same time that the Chinese Code continues to belong to the Germanic legal family, and does not want to "mix" with the Common Law.

\section{The Chinese law of contract}

\subsection{No book on obligations}

In this paper we look more in detail to Book III on Contracts of the Civil Code. ${ }^{5}$ There is no Book on Obligations. The general theory of contractual obligations and the different nominated contracts are put together in Book III, together with the quasi-contracts. In contrast to the civilian tradition, the Chinese Civil Code divides the law of obligations in two separate Books, one on Contracts and another on Torts.

\footnotetext{
${ }^{4}$ Jian Qu, "Trust as an idea. Transplantation and regeneration of trust law in China", $\mathrm{PhD}$ thesis at the university of Leuven (in preparation), 2021.

${ }^{5}$ Bing Ling, "The new contract law in the Chinese Civil Code", Chinese Journal of Comparative Law, 4 January 2021.
} 
Strange enough that is also the case in the Common-Law where contract and torts are two separate branches of the private law. The difference is, however, that the term obligation is not used in the Common Law, while the Chinese Civil Code uses the concept of obligation (yiwu).

\subsection{Book VII on tortuous liability}

Concerning the law of torts it suffices here to say that Article 1615 of Book VII contains a general fault liability principle that replicates the French Civil Code's articles 1240-1241. As novelty a provision on falling objects out of windows can be cited, implying a collective liability of all the inhabitants of the building if the culprit remains unknown. Article 1010 can also be cited, which obliges companies-in nod to the me-too movement-to adopt measures for preventing and responding to sexual harassment in workplaces and schools. These include channels for employee complaints, procedures for investigating complaints, and rules for disciplining wrongdoers.

Violation of personality rights is a tort (budangdeli). This brings us to Book IV.

\subsection{Book IV on personality rights}

The biggest structural innovation in the Code is to be found in a separate Book IV on personality rights. It includes a list of rights with a focus on privacy and data protection in order to tackle the legal challenges posed by the advancement of technology. Article 990 provides that "personality rights are rights enjoyed by civil subjects including the right to life, the right to body, the right to health, the right to one's name, the right to one's image, the right to honor, the right to reputation, the right to privacy etc."

\subsection{The quasi-contracts}

Subpart III of Book III on contracts (a hold-all tote bag) contains two new legal principles which are at the basis of what the civil law calls "quasi-contracts" (zhi hetong), although for sure they are not contracts. This concept is unknown in the Common-Law.

(a) Unjustified enrichment The importance of that principle in the civil law is vastly greater than the "unjust enrichment" in the Common Law. There are three requirements as basis of this new remedy in the Chinese Civil Code: something must have been "acquired"; it must be "at the expense" of another person, and it must have been acquired "without legal justification". For instance: a lessee executed with the consent of the lessor, but without agreement about the compensation, improvement works in the leased premises. The lessee can claim compensation for his expenses on basis of the said quasi-contract. Another example: two debtors are obliged to perform one contract. One pays the whole 
debt. He can reclaim from the other the part due by the other on basis of this quasi-contract.

(b) Negotiorum gestio (wuyinguanli) It concerns the management of affairs of another person, without a mandate given by that person. It creates a semi-contractual relation. The manager can demand compensation for his expenses from the other person under certain circumstances. An interesting example is given by the videos shown in the Chinese social media about the misadventures of a Good Samaritan and the reports in the press about the incidents, such as the Peng $\mathrm{Yu}$ incident in 2006, where a Good Samaritan who helped a woman injured in an accident, was accused of having injured the victim. In another incident a toddler, Wang Yue, was run over by two vehicles. The entire incident was caught on a video which shows 18 people seeing the injured child, but refusing to help, afraid as they were of getting into trouble themselves. In order to bring about a change in this mentality, the General Principles of Civil Law of 1 October 2017 stipulated in article 184 that "where voluntary carrying out emergency assistance causes harm to the person receiving assistance, the aider does not bear liability". This rule is now confirmed in Book I of the Civil Code. Moreover, the newly introduced remedy based on negotiorum gestio gives the aider the right to claim compensation for the damage suffered by him and for his expenses during the intervention.

\subsection{The 19 nominate contracts}

Subpart II of Book III contains the different nominate contracts. What are the novelties, or the improvements?

(a) Concerning the contract of lease it is now specified that the landlord is obliged to renew his land use right at the end of the granted time period. The land, i.e. the soil whereon the building given in lease stands, is property of the State. One can be owner of a building or an apartment, but not of the land. One can obtain the right to use a plot of land, but that land use right is temporary. At the end of the granted time period, the land use right may be renewed, but against payment of a fee. If there is a tenant, it is the duty of the landlord to obtain the renewal.

A new provision specifies another obligation of the landlord. If he plans to sell the building or apartment, he cannot invoke it as a valid reason to evict the tenant.

The Civil Code allows now termination of a contract with an unfixed contractual term at any time without a reason, provided that the other party has been informed within a reasonable period in advance.

(b) To the list in the previous Contract Law four new nominate contracts are added to the Civil Code: suretyships (transferred from an existing separate Law on Guarantees to the Civil Code), factoring contracts, contracts for the management of apartment property and partnership contracts. That makes now together 19 nominated, typical contracts. The Code now specifies that a suretyship contract will not be considered as a joint and several guarantee, if this is not clearly 
stipulated. It means that the creditor can only claim for payment of the debt from the surety after having claimed payment from the debtor and exhausted all his remedies against him.

(c) Labour contracts are left out of the Civil Code. They are regulated in the early Labour Contract Act of July 1994, which was modified in June 2007, amended again in July 2013 and regularly updated since. It is generally accepted that the principles of Book III of the Civil Code apply to labour contracts. The same can be said of the insurance contract, regulated in a separate Law.

Mortgage and pledge contracts are not regulated in Book III, but in Book II on real rights, in chapters XVII and XVIII. Unless otherwise agreed by the parties, the mortgaged property can now be transferred with a prior notice to the creditor, instead of a prior consent. The transfer will not impact the creditor's mortgage rights.

\subsection{The general theory of contractual obligations}

Subpart I of Book III contains, as was said earlier, the general theory of the contractual obligations. An eye-catcher is a new provision, article 509 which emphasizes the protection of the environment. China is a latecomer to climate seriousness. But now Xi Jinping is convinced that "ecology is key to China's renaissance and is part of the social contract between the Communist Party and the people". No wonder that article 509 emphasizes the protection of the environment when performing contracts. The parties shall avoid wasting resources, polluting the environment, and damaging the ecology during the performance of the contract.

The drafters of the Civil Code corrected and improved several existing provisions in the previous Contract Law whose text mostly was maintained. Let us give some examples.

(a) Concerning the defects which violate the consent of a contracting party (mistake, duress and fraud) there was a contradiction between the Act of 1986 on the general principles of civil law and the Contract Act of 1999. A juristic act was void if such a defect in consent was proven, while a contract was voidable. The contradiction is corrected in the Civil Code. Both, contract and juristic act are voidable. Moreover, in the previous Contract Law fraud and duress would render a contract void and null if it would "harm a State interest" according to article 52, meaning that if the aggrieved party was a State owned enterprise, the contract would be void. This provision encouraged the SOE's to renege on a bad bargain. This provision is suppressed in the Civil Code. No privileged position anymore for SOE's.

(b) Article 8 of the Civil Code provides that a contract shall respect "public order" ("gonggong zhi xu"). The Contract Law used the broader term "social and public interests" ("She hui gong gong liyi"), which allowed the People's Courts to take the concrete circumstances of the case into consideration to judge if the 
contract was contrary to public policy. ${ }^{6}$ The changed term is more in line with international practice.

(c) Departing from the vague previous article 64 of the Contract Law on Contracts for the benefit of a third party, article 522 of the Civil Code makes it now possible that the third party can directly claim from the debtor the performance of his obligations. If the debtor breaches the contract, he is directly liable towards the third party for whose benefit the contract was made.

(d) Articles 535 and 539 of the Civil Code ameliorate likewise the previous article 74 of the Contract Act concerning the "actio Pauliana", the remedy enabling a creditor to revoke the effects ("chexiao quan") of a transaction made by the debtor to the prejudice of the creditor and in fraud of his rights.

(e) The Civil Code specifies rules for the conclusion and the performance of electronic contracts.

(f) If a contract needs an approval of some administrative authority, the neglect by a party to do what is necessary to obtain the approval, will be considered a breach of contract. According to an interpretation of the SPC a People's Court may order to go through the relevant procedures.

(g) In the Anglo-American tort law punitive damages are sometimes granted to the plaintiff by the court; in Chinese contract law they are in some cases granted by the legislator. The Chinese Civil Code introduces punitive damages against intellectual property infringement.

(h) The article in the Contract Law of 1999 about the choice of law clause in foreignrelated contracts was left out of the Civil Code. This question is dealt with in the Law of 2010 on the international private law. The rules on Sino-foreign contractual joint ventures on the other hand have been abolished, when the Foreign Investment Law came into force on January 1, 2020.

\section{About the English translation of the Chinese Civil Code}

This paper could not be concluded without a word about the official English translation of the Civil Code. Such a translation should be effectuated-or at least supervised-by native speakers who are also lawyers specialized in comparative law. This is obviously not the case in China. Let us give two examples of a misleading English translation of a legal term in the Civil Code. ${ }^{7}$

(a) A first one concerns two nominate contracts in Subpart II of Book III of the Civil Code, which are related to agency. Agency in general, the legal representation of a person, is treated in chapter 7 of Book I of the Civil Code. The two

\footnotetext{
6 The Chinese law of arbitration contains the same concept of "social and public interests", allowing a People's Court to refuse the enforcement of a foreign award. See Herbots, J.H., "Les caractéristiques propres au droit de l'arbitrage de la République Populaire de Chine", b-Arbitra, 2/2014.

7 Cfr. BAZIN, Hubert (ed.), Ricci Dictionary of Chinese law / Dictionnaire Ricci du droit chinois, Brill, 2020 .
} 
mentioned nominate contracts listed in Book III are: the "wei tuo hetong" and the "hang ji hetong". The first one is in the English translation an entrustment contract or a commission contract; the second one a brokerage contract. Both translations "commission contract" and "brokerage contract" are misleading. Not discussed here is a third nominate contract, translated as an "intermediary contract", because the Chinese intermediary does not conclude the contract—unlike the English broker-and by consequence does not represent his client. The German law relating to agency differs strikingly from the English law on this topic. Any discussion of the German and Chinese law about legal representation in the English language presents insurmountable translation difficulties, one reason being that the concept of undisclosed agency is unknown to German law. On the other hand the German commercial code regulates a contract which is unknown in English law, namely the "commission contract", by which a person, desirous of purchasing or selling goods or securities through an intermediary versed in this type of business gives a mandate ("Kommission") to that intermediary ("Kommissionär"). The customer giving the mandate is known as "Kommitent". The Kommissionär dealing with a third party, acts in his own name, but for the account of the Kommittent (receiving a commission for his services). The English translation of the Chinese Civil Code calls this contract-the "hang ji hetong"- a brokerage contract, which is misleading. It is as misleading, in the light of what was said above, to translate the "wei tuo hetong" as a commission contract. It is suggested to translate the concept of "wei tuo hetong" by agency contract, or even better by mandate contract, and "hang ji hetong" by commission contract (referring to the German model "Kommission").

(b) Another example of misleading translation gives article 535 of the Chinese Civil Code concerning the "daiweiquan", the "oblique" action, translated in a bizarre way by "right of subrogation". The term subrogation in a civil law system points to a concept which is related to the payment. It indicates that if another person than the debtor, for instance a surety, pays the creditor, that person is subrogated into the place of the paid creditor. The claim of the creditor is not discharged, but passes to the person who paid, together with possible other securities held by the creditor. Article 535 concerns quite another situation. It is a remedy which enables the creditor of an insolvent debtor to exercise the neglectful debtor's actions, except those which are purely personal to him. The creditor is not "subrogated" in the rights of the neglectful debtor. He just acts as representative of the debtor, and does not exercise his own right.

\section{Conclusion}

The new Chinese Civil Code is an important milestone in the development of the Chinese private law. It will become a key component of the life of the citizen during the continuous modernizations of the governance system, and has a positive effect of providing certainty and clarity. Some commentators wrote that the French Civil Code of 1804 was the Code of the nineteenth century, and the BGB the Code of the twentieth century, while the Chinese Civil Code would be considered as the Code 
of the 21th century. This seems a bit overrated. Its legal terminology and style is not a perfect master piece, neither an innovative monument. Anyhow, after its promulgation starts the time of its interpretation, as Portalis, a preeminent member of the drafting commission of the Napoleonic Code, said in 1804. The Chinese Supreme People's Court is quite prepared to step in and in fact started to do so. A notice of the general office of the Supreme People's Court contained already before the enactment of the Civil Code in May 2020 a plan to finalize its interpretation of it. It will also clarify if the earlier interpretations of now repealed statutes which were not reformulated explicitly in the text incorporated in the Civil Code are maintained. 